\title{
Uptake of Ag, Co and Ni by the Organs of Typha domingensis (Pers.) Poir. ex Steud. in Lake Burullus and Their Potential Use as Contamination Indicators
}

\author{
Ebrahem M. Eid ${ }^{*}$, Mohamed A. El-Sheikh ${ }^{2,3}$, Abdulrahman A. Alatar ${ }^{2}$ \\ ${ }^{1}$ Botany Department, Faculty of Science, Kafr El-Sheikh University, Kafr El-Sheikh, Egypt; ${ }^{2}$ Botany \& Microbiology Department, \\ College of Science, King Saud University, Riyadh, Saudi Arabia; ${ }^{3}$ Botany Department, Faculty of Science, Damanhour University, \\ Damanhour, Egypt. \\ Email: "ebrahem.eid@gmail.com
}

Received October 24 $4^{\text {th }}, 2011$; revised November 27 $7^{\text {th }}, 2011$; accepted December $29^{\text {th }}, 2011$.

\begin{abstract}
The concentrations of Ag, $\mathrm{Co}$ and $\mathrm{Ni}$ in the sediments and the different organs of Typha domingensis from Lake Burullus, Egypt, were investigated monthly from February to September 2010 to evaluate the aquatic environment quality of the lake and to test the suitability of these organs for bio-indicating of sediment metals. The sediment heavy metals were found to decrease in the order of $\mathrm{Ni}>\mathrm{Co}>\mathrm{Ag}$. The sediment contents of $\mathrm{Ag}$ were about 45 times above the worldwide range. On the other hand, Co concentrations were below the reference ranges of United States and Chinese soils. The heavy metals bioaccumulation decreased according to the order of rhizome > root > leaf for Ag; and root > rhizome $>$ leaf for Co and Ni. It was found also that, T. domingensis had no significant differences in heavy metals concentrations over time. The transfer factors of $\mathrm{Ag}$, $\mathrm{Co}$ and $\mathrm{Ni}$ from sediment to below-ground organs were smaller than one. Co had the maximum transport from below-ground to above-ground organs, while $\mathrm{Ag}$ had the minimum. There was a significant linear correlation between the concentration of $\mathrm{Ag}$ in root of $T$. domingensis and that in sediment. This result suggested that $T$. domingensis can be regarded as bio-indicator for Ag pollution of Lake Burullus.
\end{abstract}

Keywords: Bio-indicators; Cattails; Heavy metals; Lake Burullus; Macrophytes; Wetlands

\section{Introduction}

Heavy metals are serious pollutants in natural environments due to their toxicity, persistence and bioaccumulation problems. The accumulation of heavy metals in the environment has become a concern due to the health risks to humans and animals. The problem is not restricted to soils with high metal levels, such as mining areas, but also includes those with moderate to low contamination of metals. These toxic elements are present at elevated levels mainly through human activities, as smelting, refining of non-ferrous metals, electroplating, agricultural practices, and industrial and municipal waste disposal on land [1]. Recently, there has been an increasing interest in using biological indicators such as plants for monitoring soil, air and water pollution [2-6]. Perception the environmental pollution by using biological indicators is a cheap, reliable and simple alternative to the conventional sampling methods [7].

Aquatic macrophytes are widely distributed in various wet environments, from fresh to salt water [4] and they play an important role in heavy metals cycling in the wetlands due to uptake, storage, and release processes. Spe-

${ }^{*}$ Corresponding author. cifically, plants with potentially high annual primary production can extract large amounts of heavy metals from their environment and store these metals in biomass and litter [8]. Therefore, some aquatic plants such as Eichhornia crassipes (C. Mart.) Solms, Phragmites australis (Cav.) Trin. ex Steud., Potamogeton pectinatus L. and Typha domingensis (Pers.) Poir. ex Steud. have been used to indicate, monitor and purify water pollution [3,4,8-11].

Typha domingensis (Pers.) Poir. ex Steud. is a warmtemperate and tropical regions plant that occurs everywhere in ditches and marshy places in Egypt $[12,13]$. It is one of the major components of vegetation stands along the shores of Lake Burullus close to the Deltaic Mediterranean coast [14]. T. domingensis is one of the emergent plants most commonly used in constructed wetlands for the enhancement of water quality in water treatment systems $[10,15]$ due to its high growth rate and great capacity for heavy metals accumulation in its tissues [16,17].

In the present study, $\mathrm{Ag}, \mathrm{Co}$ and $\mathrm{Ni}$ concentrations in the plant and sediment samples were analyzed in order to evaluate the aquatic environment quality of Lake Burullus, and to investigate possible relationships between 
heavy metal concentrations in the plant and sediment in order to ascertain if this plant can be used as an indicator for the heavy metal contamination of the study area.

\section{Materials and Methods}

\subsection{Study Area}

Lake Burullus is one of the Egyptian northern lakes that connected with the Mediterranean Sea through a natural outlet, Bughaz El-Burullus, (Figure 1). It is bordered from the north by the Mediterranean Sea and from south by agricultural lands of the Nile Delta. Its coordinates are $31^{\circ} 36^{\prime} \mathrm{N}$ and $30^{\circ} 33^{\prime} \mathrm{E}$ in north-west, $31^{\circ} 36^{\prime} \mathrm{N}$ and $31^{\circ} 07^{\prime} \mathrm{E}$ in the north-east, $31^{\circ} 22^{\prime} \mathrm{N}$ and $30^{\circ} 33^{\prime} \mathrm{E}$ in the south-east, $31^{\circ} 22^{\prime} \mathrm{N}$ and $31^{\circ} 07^{\prime} \mathrm{E}$ in the south-west. The lake extends for a distance of $47 \mathrm{~km}$ along the NE-SW axis with oblong shape of a total area of $410 \mathrm{~km}^{2}$. The depth of this lake varies between $20 \mathrm{~cm}$ close to the shore of the eastern basin and $200 \mathrm{~cm}$ at the middle basin and near the sea outlet. A marine sand bar separates the Mediterranean coast from the lake shore, with a width that varies between a few hundred meters near the sea outlet till a maximum of $6 \mathrm{~km}$ in the west [18]. The main human activity in Lake Burullus is fish production, with fish yield of 52,000 ton $\mathrm{yr}^{-1}$ [19]. It is one of the major disposal areas that receives most of the drainage water of the Nile Delta' agricultural lands which feeds the lake with about 4 billion $\mathrm{m}^{3} \cdot \mathrm{yr}^{-1}$ [20]. Also it receives fish farms and industrial drainage water [18]. It is alkaline, shallow, brackish, and polluted lake [8]. The Mediterranean deltaic coast, in which this lake occurs, belongs to the arid region where the climatic conditions are warm summers $\left(20^{\circ} \mathrm{C}-30^{\circ} \mathrm{C}\right)$ and mild winters $\left(10^{\circ} \mathrm{C}-20^{\circ} \mathrm{C}\right)$.

\subsection{Sample Collection}

Sampling was carried out at three locations of Lake Burullus and three sampling sites were randomly chosen in each location (Figure 1). In each sampling site, leaves, rhizomes and roots of $T$. domingensis were collected monthly from February to September 2010 from more than 10 individual plants within a $100 \mathrm{~m}^{2}$, and then they were mixed up to form a composite plant sample. At each sampling site, one sediment sample was collected monthly close to sampling plants as a profile of $20 \mathrm{~cm}$ depth.

\subsection{Sample Analysis}

The plant samples were washed thoroughly with tap water and rinsed with deionized water, then dried at $85^{\circ} \mathrm{C}$ in an oven to constant weight after that was ground into a powder using a metal-free plastic mill. The sediments were air dried at room temperature and passed through $2 \mathrm{~mm}$ sieve to separate gravel and debris. Plant samples were digested with concentrated $\mathrm{HNO}_{3}$ and $\mathrm{HClO}_{4}(87: 13, \mathrm{v} / \mathrm{v})$, while sediment samples with concentrated $\mathrm{HF}: \mathrm{HNO}_{3}: \mathrm{HClO}_{4}$ (4:1:1, v/v) [21]. Estimation of Ag, $\mathrm{Co}$ and $\mathrm{Ni}$ was carried out by Atomic absorption (Shimadzu AA-6200). All these procedures are according to Allen [22].

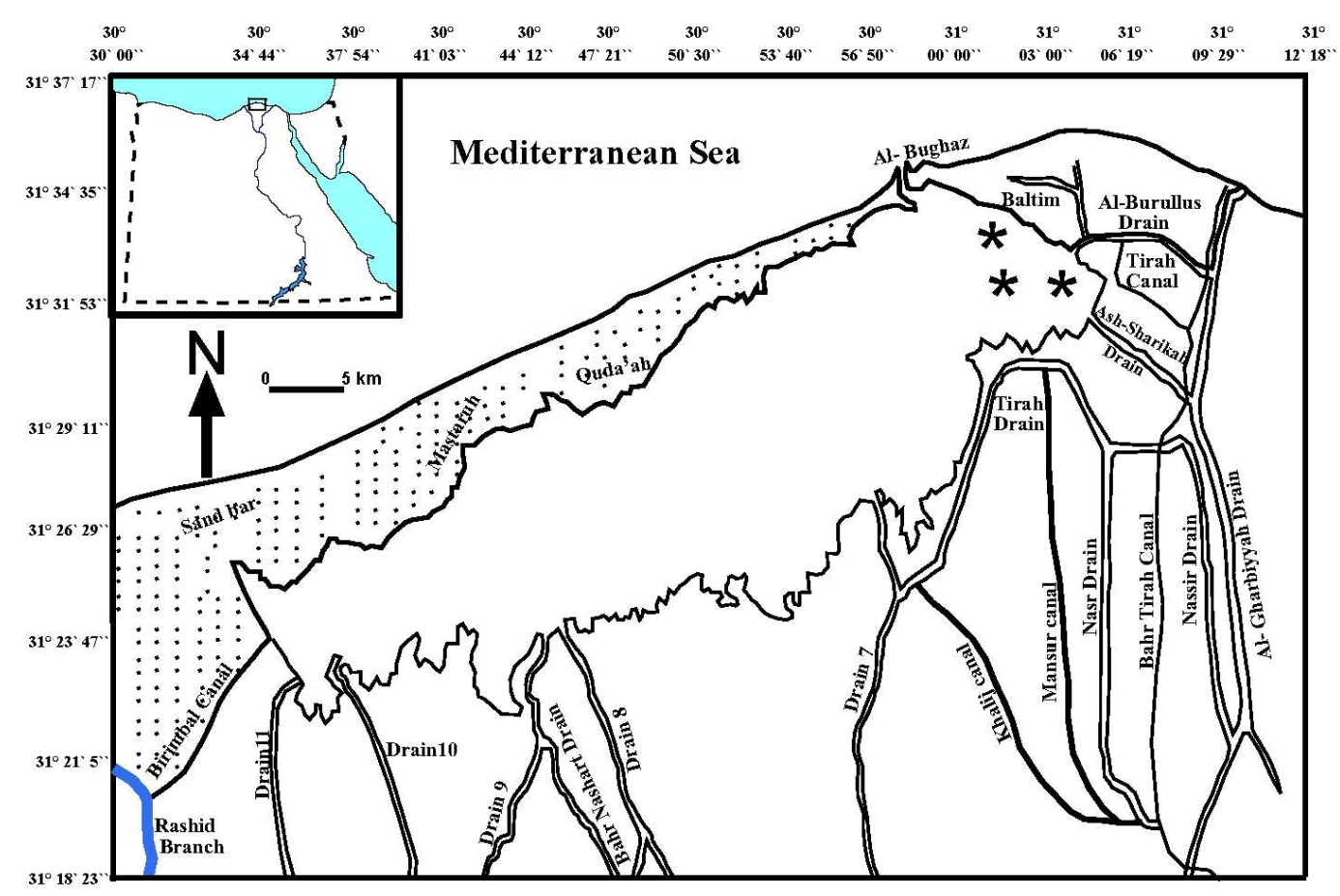

Figure 1. Map of Lake Burullus (Egypt) indicating the three sampling locations by asterisks. 


\subsection{Statistical Analysis}

The significance of variation in heavy metal concentrations in sediment supporting the growth of $T$. domingensis was assessed using one-way ANOVA. The signifycance of variation in heavy metals of $T$. domingensis organs in relation to plant organs over time were assessed using repeated measurement ANOVAs. We used the correlation procedures to evaluate statistical relationships between heavy metals of plant organs and sediment. All statistical analyses were carried out using software SPSS version 15.0 of Statistical Software Package [23].

The translocation of heavy metals from sediment to plant tissues was assessed following transfer factor (TF). It was calculated to determine the relative uptake of heavy metals by the plants with respect to sediment [24]: $\mathrm{TF}=$ Concentration of metals in plant body $\left(\mathrm{mg}^{\mathrm{kg}} \mathrm{kg}^{-1}\right) /$ Concentration of metals in sediment $\left(\mathrm{mg} \cdot \mathrm{kg}^{-1}\right)$ at that site.

\section{Results}

In sediment, the heavy metals were found to decrease in the order of Ni $>\mathrm{Co}>\mathrm{Ag}$ (Table 1). No significant differences in sediment heavy metals concentrations were found over time. The concentrations of $\mathrm{Ag}$ ranged from $5.28 \mathrm{mg} \cdot \mathrm{kg}^{-1}$ in April to $6.33 \mathrm{mg} \cdot \mathrm{kg}^{-1}$ in August with annual mean $5.86 \mathrm{mg} \cdot \mathrm{kg}^{-1}$; Co ranged from $11.85 \mathrm{mg} \cdot \mathrm{kg}^{-1}$ in July to $14.07 \mathrm{mg} \cdot \mathrm{kg}^{-1}$ in May with annual mean 13.06 $\mathrm{mg} \cdot \mathrm{kg}^{-1}$; Ni ranged from $21.57 \mathrm{mg} \mathrm{kg}^{-1}$ in April to 27.65 $\mathrm{mg} \cdot \mathrm{kg}^{-1}$ in March with annual mean $25.07 \mathrm{mg} \cdot \mathrm{kg}^{-1}$.

Heavy metals concentrations in the organs of $T$. domingensis are shown in (Figure 2). The bioaccumulation decreased according to the order of rhizome $>$ root $>$ leaf for $\mathrm{Ag}$; and root $>$ rhizome $>$ leaf for $\mathrm{Co}$ and $\mathrm{Ni}$. The heavy metals of the plant organs were found to decrease in the same order of sediment $(\mathrm{Ni}>\mathrm{Co}>\mathrm{Ag})$. It was found that $T$. domingensis had no significant differences in heavy metals concentrations over time. $\mathrm{Ag}, \mathrm{Co}$ and $\mathrm{Ni}$ concentrations ranged between $1.24-3.09,3.64-6.63$ and $5.08-15.39 \mathrm{mg} \cdot \mathrm{kg} \cdot \mathrm{DW}^{-1}$ in leaf; $1.12-3.87,4.48-$ 6.89 and $10.44-17.44 \mathrm{mg} \cdot \mathrm{kg} \cdot \mathrm{DW}^{-1}$ in root; $1.23-6.89$, $2.08-8.69$ and $6.52-20.99 \mathrm{mg} \cdot \mathrm{kg} \cdot \mathrm{DW}^{-1}$ in rhizome, respectively (Figure 2).
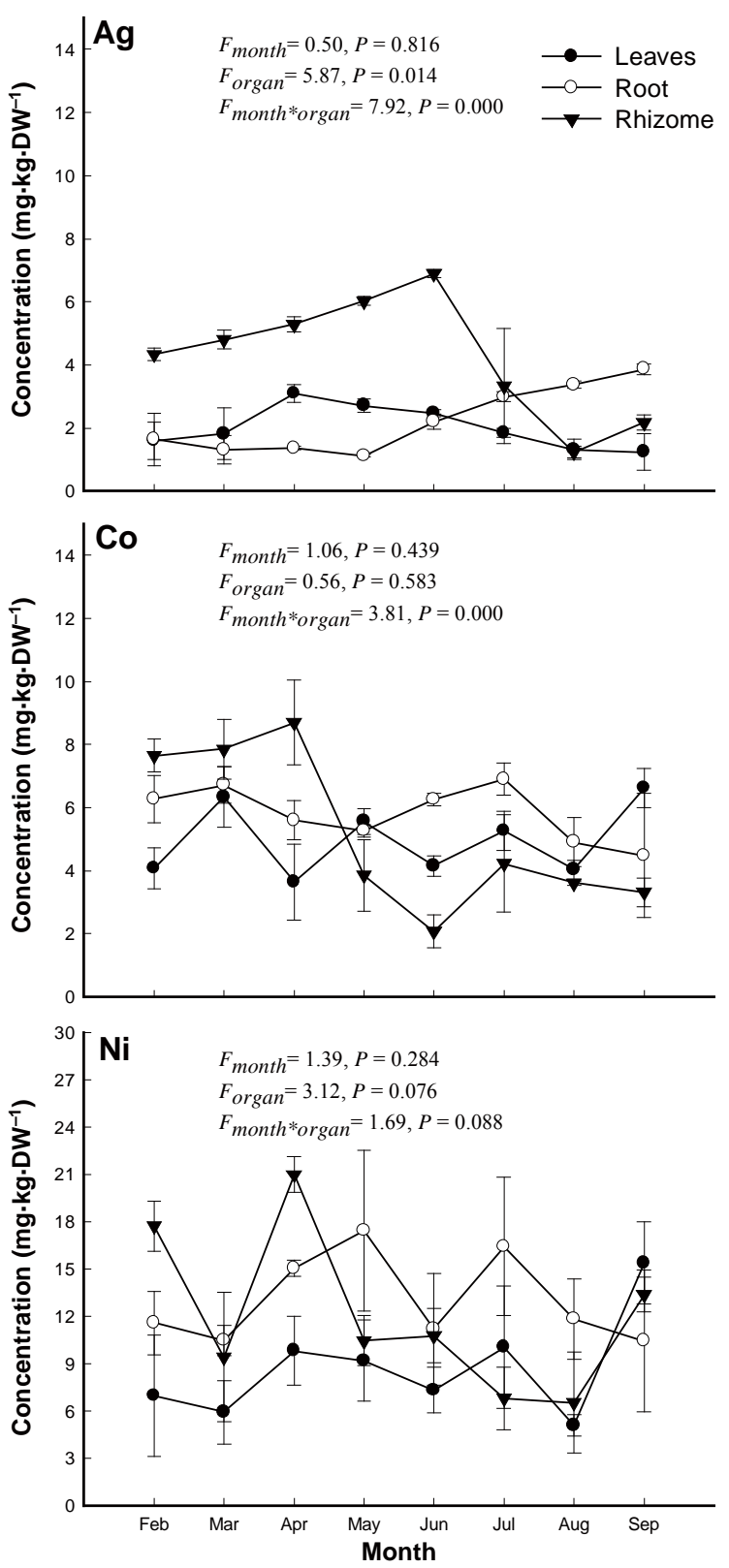

Figure 2. Monthly mean and standard error (vertical bars) of Ag, Co and Ni concentrations of Typha domingensis organs in Lake Burullus.

Table 1. Monthly mean ( $1^{\text {st }}$ line) and standard error ( $2^{\text {nd }}$ line) of Ag, Co and Ni concentrations in sediment supporting the growth of Typha domingensis in Lake Burullus. F-values represent the one way ANOVA. The minimum and maximum values are in the bold letters.

\begin{tabular}{|c|c|c|c|c|c|c|c|c|c|c|c|}
\hline \multirow{2}{*}{ Site } & \multicolumn{8}{|c|}{ Month } & \multirow{2}{*}{$\begin{array}{c}\text { Annual } \\
\text { mean }\end{array}$} & \multirow{2}{*}{ F-value } & \multirow{2}{*}{$P$} \\
\hline & Feb. & Mar. & Apr. & May & Jun. & Jul. & Aug. & Sep. & & & \\
\hline $\mathrm{Ag}\left(\mathrm{mg} \cdot \mathrm{kg}^{-1}\right)$ & $\begin{array}{l}5.35 \\
0.71\end{array}$ & $\begin{array}{l}5.47 \\
0.63\end{array}$ & $\begin{array}{l}\mathbf{5 . 2 8} \\
0.73\end{array}$ & $\begin{array}{l}5.88 \\
0.47\end{array}$ & $\begin{array}{l}6.01 \\
0.48\end{array}$ & $\begin{array}{l}6.25 \\
0.72\end{array}$ & $\begin{array}{l}\mathbf{6 . 3 3} \\
0.59\end{array}$ & $\begin{array}{l}6.32 \\
0.69\end{array}$ & $\begin{array}{l}5.86 \\
0.21\end{array}$ & 0.485 & 0.832 \\
\hline $\mathrm{Co}\left(\mathrm{mg} \cdot \mathrm{kg}^{-1}\right)$ & $\begin{array}{c}11.97 \\
0.92\end{array}$ & $\begin{array}{c}13.76 \\
0.72\end{array}$ & $\begin{array}{c}12.95 \\
1.45\end{array}$ & $\begin{array}{c}\mathbf{1 4 . 0 7} \\
0.55\end{array}$ & $\begin{array}{c}13.39 \\
0.43\end{array}$ & $\begin{array}{c}\mathbf{1 1 . 8 5} \\
0.59\end{array}$ & $\begin{array}{c}13.23 \\
0.80\end{array}$ & $\begin{array}{c}13.23 \\
1.17\end{array}$ & $\begin{array}{c}13.06 \\
0.30\end{array}$ & 0.783 & 0.611 \\
\hline $\mathrm{Ni}\left(\mathrm{mg} \cdot \mathrm{kg}^{-1}\right)$ & $\begin{array}{c}24.29 \\
0.80\end{array}$ & $\begin{array}{c}\mathbf{2 7 . 6 5} \\
1.69\end{array}$ & $\begin{array}{c}\mathbf{2 1 . 5 7} \\
1.48\end{array}$ & $\begin{array}{c}23.41 \\
1.28\end{array}$ & $\begin{array}{c}25.19 \\
5.59\end{array}$ & $\begin{array}{c}25.73 \\
1.86\end{array}$ & $\begin{array}{c}26.63 \\
3.48\end{array}$ & $\begin{array}{c}26.07 \\
4.75\end{array}$ & $\begin{array}{c}25.07 \\
0.99\end{array}$ & 0.390 & 0.895 \\
\hline
\end{tabular}


The transfer factors of $\mathrm{Ag}$, Co and Ni from sediment to below-ground organs were smaller than one. Co had the maximum transport from below-ground to above-ground organs, while Ag had the minimum (Table 2). Ag accumulated in higher concentration in roots grown in sediment containing greater amount of this element $(r=0.56$, $P<0.01$; Table 3). Significantly positive correlation was found between Co contents in roots and the level of $\mathrm{Ni}$ element in sediment $(r=0.41, P<0.05)$.

\section{Discussion}

Silver is very toxic to heterotrophic bacteria and thus is widely used as an aseptic substance [25]. However, some bacteria (e.g., Thiobacillus ferrooxidans) are capable of accumulating great amounts of Ag [26]. Ag compounds are known to precipitate bacterial proteins as well as to form insoluble complexes with ribonucleic acids [27]. The average Ag content for worldwide soils is estimated as $0.13 \mathrm{mg} \cdot \mathrm{kg}^{-1}$, and range of its mean contents in soils of various countries is 0.05 and $0.13 \mathrm{mg} \cdot \mathrm{kg}^{-1}$ [25]. In the present study, Ag concentrations of Lake Burullus sediment were about 45 times above the worldwide range. Concentrations of $\mathrm{Ag}$ in plants were reported by Smith and Carson [28] to range from 0.03 to $0.5 \mathrm{mg} \cdot \mathrm{kg}^{-1}$. Chapman [29] established the intermediate range of $\mathrm{Ag}$ in plant foodstuffs as 0.07 to $2.0 \mathrm{mg} \cdot \mathrm{kg}^{-1}$. In the present study, the average concentrations of Ag were 2.01, 2.23 and $4.26 \mathrm{mg} \cdot \mathrm{kg}^{-1}$ in leaves, roots and rhizomes of $T$. domingensis, respectively; and these detected values were not in the phytotoxic range $\left(>5.04 \mathrm{mg} \cdot \mathrm{kg}^{-1}\right)$ reported by Cunningham and Stroube [30].

Most of Co is used for special alloys utilized in several industries. It is also used in chemical catalysis and synthesis, as well as a plastic hardener. In pharmacy Co is used for medical and veterinarian drugs. The radionuclide ${ }^{60} \mathrm{Co}$ is applied for some medical treatments [25]. Cobalt is an essential micro-nutrient for animals, being part of the structure of vitamin $\mathrm{B}_{12}$, and is involved with certain enzymes. The essentiality of Co for both bluegreen algae and microorganisms in fixing $\mathrm{N}_{2}$ is now well established [25]. Plants require only minute amounts mainly for catalytic functions and levels are often $<5$ $\mathrm{mg} \cdot \mathrm{kg}^{-1}$ dry weight [22]. The range of Co in reference soil samples of United States is from 5.5 to $29.9 \mathrm{mg} \cdot \mathrm{kg}^{-1}$ and in Chinese soils, in the range of $5.5-97.0 \mathrm{mg} \cdot \mathrm{kg}^{-1}$ [31]. In the present study, Co concentrations of sediment were below the reference ranges of the United States and Chinese soils. Different concentrations of Co in plant tissues have been reported to produce toxicity symptoms, as follows (in $\mathrm{mg} \cdot \mathrm{kg}^{-1}$ ): 43 - 142 in bush beans [32]; 19 32 in Sudan grass [33]; and 6 in barley seedlings [34]. However, commonly reported critical Co levels in plants range from 30 to $40 \mathrm{mg} \cdot \mathrm{kg}^{-1}$ [35]. In the present study, Co concentrations of $T$. domingensis organs were below the phytotoxic range $\left(30-40 \mathrm{mg} \cdot \mathrm{kg}^{-1}\right)$.

Table 2. Mean and standard error (SE) of the transfer factor of Ag, Co and Ni from sediment to roots (RT/SE), sediment to rhizomes (RE/SE), below- to above-ground organs (AG/BG) in Typha domingensis in Lake Burullus.

\begin{tabular}{cccccccc}
\hline & \multicolumn{9}{c}{ Transfer factor } \\
\cline { 2 - 9 } & Mean & RT/SE & RE/SE & Mean & AG/BG \\
Ag & 0.40 & 0.03 & 0.75 & 0.08 & 0.88 & 0.09 \\
$\mathrm{Co}$ & 0.46 & 0.03 & 0.41 & 0.05 & 1.18 & 0.13 \\
$\mathrm{Ni}$ & 0.55 & 0.06 & 0.51 & 0.06 & 0.89 & 0.12 \\
\hline
\end{tabular}

Table 3. Pearson correlation coefficient (r-values) between Ag, Co and Ni concentrations of sediment and plant organs of Typha domingensis in Lake Burullus. The significant values are in the bold letters. $* P<0.05, * * P<0.01$.

\begin{tabular}{|c|c|c|c|c|c|c|c|c|c|c|c|}
\hline & Leaf $_{A g}$ & $\operatorname{Root}_{A g}$ & Rhizome $_{A g}$ & Sediment $_{A g}$ & Leaf $_{C o}$ & $\operatorname{Root}_{C o}$ & Rhizome $_{C o}$ & Sediment $_{C o}$ & Leaf $_{N i}$ & $\operatorname{Root}_{N i}$ & Rhizome $_{N i}$ \\
\hline $\operatorname{Root}_{A g}$ & $-0.499 *$ & & & & & & & & & & \\
\hline Rhizome $_{A g}$ & $0.493 *$ & $-0.542 * *$ & & & & & & & & & \\
\hline Sediment $_{A g}$ & -0.231 & $0.564 * *$ & 0.038 & & & & & & & & \\
\hline Leaf $_{C o}$ & -0.257 & 0.087 & -0.093 & -0.003 & & & & & & & \\
\hline $\operatorname{Root}_{C o}$ & -0.119 & -0.270 & 0.233 & -0.090 & 0.134 & & & & & & \\
\hline Rhizome $_{C o}$ & 0.187 & $-0.415^{*}$ & 0.158 & -0.306 & 0.018 & 0.073 & & & & & \\
\hline Sediment $_{C o}$ & 0.148 & -0.118 & 0.180 & -0.171 & 0.017 & -0.383 & -0.160 & & & & \\
\hline Leaf $_{N i}$ & 0.062 & 0.136 & -0.078 & 0.220 & 0.249 & 0.002 & -0.040 & -0.119 & & & \\
\hline $\operatorname{Root}_{N i}$ & 0.078 & -0.026 & 0.122 & 0.170 & -0.016 & 0.140 & 0.205 & -0.040 & 0.323 & & \\
\hline Rhizome $_{N i}$ & 0.298 & -0.190 & 0.273 & -0.008 & -0.324 & -0.307 & $0.528 * *$ & -0.071 & 0.191 & 0.094 & \\
\hline Sediment $_{N i}$ & -0.336 & 0.077 & -0.183 & -0.023 & 0.140 & $0.411 *$ & -0.224 & 0.084 & 0.160 & -0.097 & -0.266 \\
\hline
\end{tabular}


Nickel is considered as a serious pollutant that is released from metal processing plants and from the increased combustion of coal and oil. Also some sewage sludge and phosphate fertilizers may be importance sources of $\mathrm{Ni}$ in agricultural soils. There is no evidence of an essential role of Ni in plant metabolism [25]. Soils throughout the world contain $\mathrm{Ni}$ in the very broad range, however its mean concentrations, as reported for various countries are within the range $13-37 \mathrm{mg} \cdot \mathrm{kg}^{-1}$ [25]. In the present study, Ni concentrations in sediment were in the world range. The phytotoxic Ni concentrations range widely among plant species and cultivars from 40 to 246 $\mathrm{mg} \cdot \mathrm{kg}^{-1}$ [33]. Davis et al. [34] found the toxic Ni content of barley seedlings to be as low as $26 \mathrm{mg} \cdot \mathrm{kg}^{-1}$, whereas Khalid and Tinsley [36] found $50 \mathrm{mg} \cdot \mathrm{kg}^{-1} \mathrm{Ni}$ in ryegrass to cause slight chlorosis. The mean $\mathrm{Ni}$ values detected in $T$. domigensis organs were below the phytotoxic range $\left(26-246 \mathrm{mg} \cdot \mathrm{kg}^{-1}\right)$.

The transfer factor generally showed the movement of heavy metals from sediment to root and shoot, indicating the efficiency to uptake of the bio-available metals from the environment and gives an idea whether the plant is an accumulator, excluder or indicator [37]. Zu et al. [38] reported that $\mathrm{TF}>1$ were determined in metal accumulating plants, whereas TF was typically $<1$ in metal excluding plants. In the present study, the mean $\mathrm{TF}$ for $\mathrm{Ag}$, $\mathrm{Co}$ and $\mathrm{Ni}$ from sediment to below-ground organs were lower than one. That may be partly attributed to the fact that the TF was calculated based on the total metal concentrations in sediment instead of the bioavailable fractions, which are the dominant form for metal uptake by plant roots [39]. The mean TF for Ag and Ni from below- to above-ground tissues were lower than one, which means that $T$. domingensis is metal excluding plant and did not effectively transfer $\mathrm{Ag}$ and $\mathrm{Ni}$ from below-to above-ground tissues. On the other hand, the higher translocation ratio of Co in $T$. domingensis shoots make it suitable for Co phytoextraction from sediment. The differences in TF values indicated that each metal has different phytotoxic effect on $T$. domingensis [40]. In addition, these results could be related to differences in solubility and availability of each heavy metal ion [41]. Variability of within-plant distribution of $\mathrm{Ag}, \mathrm{Co}$ and $\mathrm{Ni}$ in $\mathrm{T}$. domingensis may be also due to compartmentalization and translocation in the vascular system [41]. These mechanisms are poorly understood and need further study.

There was a significant linear correlation between the concentration of $\mathrm{Ag}$ in root of $T$. domingensis and that in sediment. This result suggested that $T$. domingensis can be regarded as bio-indicator for $\mathrm{Ag}$ pollution of Lake Burullus, defined as organisms providing quantitative assessment of the environmental quality. However, no significant relationships were found between $\mathrm{Co}$ and $\mathrm{Ni}$ concentrations in $T$. domingensis organs and those in sediment. This may be partly attributed to the fact that the correlation was developed based on the total metal concentrations in sediment instead of the bioavailable fractions [39].

In conclusion, $T$. domingensis in Lake Burullus could be regarded as bio-indicator on the Ag pollution and a suitable green filter to reduce the pollution load reaching the lake, if the above-ground biomass is harvested at the maximum biomass. In Lake Burullus, the above-ground biomass reached the maximum value in July $\left[6327 \mathrm{~g} \cdot \mathrm{m}^{-2}\right.$; 11], as much as (in $\mathrm{mg} \mathrm{m}^{-2}$ ) $11.64 \mathrm{Ag}, 33.32 \mathrm{Co}$ and $63.52 \mathrm{Ni}$ could be theoretically removed annually from the lake by harvesting above-ground biomass of $T$. domingensis in July. Thus, we recommend removing the shoots immediately after cutting to avoid heavy metals leaching from shoots to sediment and water. However, over the long term, annual harvesting may lead to the deterioration of $T$. domingensis primary productivity. Thus for the sustainable use of $T$. domingensis stands, harvests should not be conducted annually; perhaps harvest rotation could be used (similar to crop rotation in farming).

\section{Acknowledgments}

This project was supported by the Center of Excellence in Biodiversity Research, King Saud University for encouragement and support.

\section{REFERENCES}

[1] S. M. Ross, "Toxic Metal in Soil-Plant Systems,". Wiley, Chichester, 1994.

[2] F. B. Pyatt, "Comparison of Foliar and Stem Bioaccumulation of Heavy Metals by Corsican pines in the Mount Olympus Area of Cyprus," Ecotoxicology and Environmental Safety, Vol. 42, No. 1, 1999, pp. 57-61. doi:10.1006/eesa.1998.1726

[3] K. Peng, C. Luo, L. Lou, X. Li and Z. Shen, "Bioaccumulation of Heavy Metals by the Aquatic Plants Potamogeton pectinatus L. and Potamogeton malaianus Miq. and Their Potential Use for Contamination Indicators and in Wastewater Treatment," Science of The Total Environment, Vol. 392, No. 1, 2008, pp. 22-29. doi:10.1016/j.scitotenv.2007.11.032

[4] G. Bonanno and R. L. Giudice, "Heavy Metal Bioaccumulation by the Organs of Phragmites australis (common reed) and Their Potential Use as Contamination Indicators," Ecological Indicators, Vol. 10, 2010, No. 3, pp. 639-645.

[5] M. Ruiz and J. Velasco, "Nutrient Bioaccumulation in Phragmites australis: Management Tool for Reduction of Pollution in the Mar Menor," Water, Air, \& Soil Pollution, Vol. 205, No. 1-4, 2010, pp. 173-185. doi:10.1007/s11270-009-0064-2 
[6] M. N. Al-Yemni, H. Sher, M. A. El-Sheikh and E. M. Eid, "Bioaccumulation of Nutrient and Heavy Metals by Calotropis procera and Citrullus colocynthis and Their Potential Use as Contamination Indicators," Scientific Research and Essays, Vol. 6, No. 4, 2011, pp. 966-976.

[7] R. Zurayk, B. Sukkariah and R. Baalbaki, "Common Hydrophytes as Bioindicators of Nickel, Chromium and Cadmium Pollution," Water, Air, \& Soil Pollution, Vol. 127, No. 1-4, 2001, pp. 373-388. doi:10.1023/A:1005209823111

[8] E. M. Eid, K. H. Shaltout, Y. M. Al-Sodany, K. Soetaert and K. Jensen, "Modeling Growth, Carbon Allocation and Nutrient Budget of Phragmites australis in Lake Burullus, Egypt," Wetlands, Vol. 30, No. 2, 2010, pp. 240251.

[9] B. C. Wolverton and R. C. McDonald, "Bioaccumulation and Detection of Trace Levels of Cadmium in Aquatic Systems by Eichhornia crassipes," Environmental Health Perspectives, Vol. 27, No. 1, 1978, pp. 161-164. doi:10.1289/ehp.7827161

[10] N. T. Abdel-Ghani, A. K. Hegazy, G. A. El-Cheghaby and E. C. Lima, "Factorial Experimental Design for Biosorption of Iron and Zinc Using Typha domingensis Phytomass," Desalination, Vol. 249, No. 1, 2009, pp. 343347. doi:10.1016/j.desal.2009.02.065

[11] E. M. Eid, K. H. Shaltout and T. Asaeda, "Modeling growth dynamics of Typha domingensis (Pers.) Poir. ex Steud. in Lake Burullus, Egypt," Ecological Modelling, 2012.

[12] L. Boulos, "Flora of Egypt, Monocotyledons (Altismataceae-Orchidaceae)," Al-Hadara Publishing, Cairo, 2005.

[13] V. Täckholm, "Students' Flora of Egypt," Cairo University Press, Cairo, 1974.

[14] K. H. Shaltout and Y. M. Al-Sodany, "Vegetation Analysis of Burullus Wetland: a RAMSAR Site in Egypt," Wetlands Ecology and Management, Vol. 16, No. 5, 2008, pp. 421-439. doi:10.1007/s11273-008-9079-5

[15] M. A. El-Sheikh, H. I. Saleh, D. E. El-Quosy and A. A. Mahmoud, "Improving Water Quality in Polluted Drains With Free Water Surface Constructed Wetlands," Ecological Engineering, Vol. 36, No. 10, 2010, pp. 1478-1484. doi:10.1016/j.ecoleng.2010.06.030

[16] B. Lorenzen, H. Brix, I. A. Mendelssohn, K. L. McKee and S. L. Miao,"Growth, Biomass Allocation and Nutrient Use Efficiency in Cladium jamaicense and Typha domingensis as Affected by Phosphorus and Oxygen Availability," Aquatic Botany, Vol. 70, No. 2, 2001, pp. 117133. doi:10.1016/S0304-3770(01)00155-3

[17] S. Newman, J. B. Grace and J. W. Koebel, "Effects of Nutrient and Hydroperiod on Typha, Cladium and Eleocharis: Implications for Everglades Restoration," Journal of Applied Ecology, Vol. 6, No. 3, 1996, pp. 774-783. doi: $10.2307 / 2269482$

[18] K. H. Shaltout and M. T. Khalil, "Lake Burullus: Burullus Protected Area," Publication of National Biodiversity Unit, Cairo, 2005.

[19] M. T. Khalil and F. A. El-Dawy, "Ecological Survey of
Burullus Nature Protectorate: Fishes and Fisheries," MedWetCoast, Global Environmental Facility (GEF) and Egyptian Environmental Affairs Agency (EEAA), Cairo, 2002.

[20] I. El-Shinnawy, "Al-Burullus Wetland's Hydrological Study," MedWetCoast, Global Environmental Facility (GEF) and Egyptian Environmental Affairs Agency (EEAA), Cairo, 2002.

[21] F. J. Zhao, S. P. McGrath and A. R. Croslant, "Comparison of Three Wet Digestion Methods for the Determination of Plant Sulpher by Inductively Coupled Plasma Atomic Emission Spectrometry (ICP-AES)," Communications in Soil Science and Plant Analysis, Vol. 25, No. 3-4, 1994, pp. 407-418. doi:10.1080/00103629409369047

[22] S. Allen, "Chemical Analysis of Ecological Materials," Blackwell Scientific Publications, London, 1989.

[23] SPSS, “SPSS Base 15.0 User's Guide," SPSS Inc., Chicago, 2006.

[24] A. C. Chamberlin, "Fallout of Lead and Uptake by Crops," Atmospheric Environment, Vol. 17, No. 4, 1983, pp. 693706. doi:10.1016/0004-6981(83)90416-X

[25] A. Kabata-Pendias, "Trace Elements in Soils and Plants," CRC Press, Boca Raton, 2011.

[26] A. B. Mukherjee, "The Use and Release of Silver in Finland," Finnish Environment, Vol. 33, No. 1, 1997, pp. 1-49.

[27] E. D. Weinberg, "Microorganisms and Minerals," Marcel Dekker, New York, 1977.

[28] I. C. Smith and B. L. Carson, "Trace Metals in the Environment," Ann Arbor Scientific Publications, Ann Arbor, MI, 1977.

[29] H. D. Chapman, "Diagnostic Criteria for Plants and Soils," University of California, Riverside, 1972.

[30] S. D. Cunningham and W. R. Stroube, "Application of an Instrumental Neutron Activation Analysis Procedure to Analysis of Food," Science of the Total Environment, Vol. 63 , No. 1,1987 , pp. 29-43. doi:10.1016/0048-9697(87)90034-9

[31] K. Govindaraju, "Compilation of Working Values and Sample Description for 383 Geostandards," Geostandards Newsletter, Vol. 18, No. 1, 1994, pp. 1-158.

[32] A. Wallace, G. V. Alexander and F. M. Chaudhry, "Phytotoxicity of Cobalt, Vanadium, Titanium, Silver and Chromium," Communications in Soil Science and Plant Analysis, Vol. 8, No. 9, 1977, pp. 751-756. doi:10.1080/00103627709366769

[33] L. P. Gough, H. T. Shacklette and A. A. Case, "Element Concentrations Toxic to Plants, Animals, and Man," US Geological Survey Bulletin, Vol. 1466, No. 1, 1979, pp. 1-80.

[34] R. D. Davis, P. H. T. Beckett and E. Wollan, "Critical Levels of Twenty Potentially Toxic Elements in Young Spring Barley," Plant and Soil, Vol. 49, No. 2, 1978, pp. 395-408. doi:10.1007/BF02149747

[35] R. D. Macnicol and P. H. T. Beckett, "Critical Tissue Concentrations of Potentially Toxic Elements," Plant and Soil, Vol. 85, No. 1, 1985, pp. 107-129. doi:10.1007/BF02197805 
[36] B. Y. Khalid and J. Tinsley, "Some Effects of Nickel Toxicity on Ryegrass," Plant and Soil, Vol. 55, No. 1, 1980, pp. 139-145. doi:10.1007/BF02149717

[37] S. Bose, J. Vedamati, V. Rai and A. L. Ramanathan, "Metal Uptake and Transport by Typha angustata L. Grown on Metal Contaminated Waste Amended Soil: an Implication of Phytoremediation," Geoderma, Vol. 145, No. 1-2, 2008, pp. 136-142. doi:10.1016/j.geoderma.2008.03.009

[38] Y. Q. Zu, Y. Li, J. J. Chen, H. Y. Chen, L. Qin and C. Schvartz, "Hyperaccumulation of $\mathrm{Pb}, \mathrm{Zn}$ and $\mathrm{Cd}$ in Herbaceous Grown on Lead-Zinc Mining Area in Yunnan, China," Environment International, Vol. 31, No. 5, 2005, pp. 755-762.doi:10.1016/j.envint.2005.02.004
[39] A. J. Cardwell, D. W. Hawker and M. Greenway, "Metal Accumulation in Aquatic Macrophytes from Southeast Queensland, Australia," Chemosphere, Vol. 48, No. 7, 2002, pp. 653-663. doi:10.1016/S0045-6535(02)00164-9

[40] M. Ruiz and J. Velasco, "Nutrient Bioaccumulation in Phragmites australis: Management Tool for Reduction of Pollution in the Mar Menor," Water, Air, \& Soil Pollution, Vol. 205, No. 1-4, 2010, pp. 173-185. doi:10.1007/s11270-009-0064-2

[41] I. S. Kim, K. H. Kang, P. Johnson-Green and E. J. Lee, "Investigation of Heavy Metal Accumulation in Polygonum thunbergii for Phytoextraction," Environmental Pollution, Vol. 126, No. 2, 2003, pp. 235-243. doi:10.1016/S0269-7491(03)00190-8 